Article

\title{
Backcasting for Sustainable Employment: A Hungarian Experience
}

\author{
Alexandra Köves ${ }^{1, *}$, Gábor Király ${ }^{2}$, György Pataki ${ }^{1,3}$ and Bálint Balázs ${ }^{3}$ \\ 1 Corvinus University of Budapest, Fővám tér 8, Budapest 1093, Hungary; \\ E-Mail: gyorgy.pataki@uni-corvinus.hu \\ 2 Budapest Business School, Buzogány u. 10-12., Budapest 1149, Hungary; \\ E-Mail: kiraly.gabor@pszfb.bgf.hu \\ 3 Environmental Social Science Research Group, Szent István University, Páter Károly u. 1., \\ Gödöllő 2100, Hungary; E-Mail: balazs.balint@essrg.hu
}

* Author to whom correspondence should be addressed; E-Mail: koves.alexandra@gmail.com; Tel.: +36-30-625-2951; Fax: +36-1-224-0859.

Received: 10 May 2013; in revised form: 1 July 2013 / Accepted: 3 July 2013 /

Published: 10 July 2013

\begin{abstract}
Sustainability and employment are terms seldom used together. Especially when defining sustainability in the stricter sense of the word, delineating a world where strong sustainability is the norm, it is problematic to deduct which elements may compose sustainable employment. In the relevant discourse, two distinct directions can be identified. Ecological modernization promises "quick fixes" to employment problems while reducing environmentally harmful economic activities without initiating major changes either in our ways of thinking or in our way of living. At the same time, the radical change paradigm disposes of the concepts of the free market society and believes that new "great transformations" are unavoidable, whereby values must change just as much as institutions. Yet, how far have these normative theoretical approaches penetrated our everyday thinking? The paper builds upon the experience of a backcasting project on sustainable employment conducted in Hungary in 2012 and early 2013 and suggests that when people are given the chance to leave the path dependencies of today behind and imagine a sustainable future, their normative visions provide us with invaluable insight as to what may constitute sustainable employment. It also contributes towards our understanding of which policy tools lead us towards a more sustainable world of work in particular and a more sustainable society in general.
\end{abstract}


Keywords: backcasting; ecological modernization; Hungary; sustainable employment; transition management; radical change paradigm

\section{Introduction}

In political and policy rhetoric, the term "sustainability" has become commonplace. Existing strategic policy documents on all levels of governance, as well as public speeches are inundated with goals of establishing a transition to a sustainable society, including the objective of "green growth" in employment [1-3]. Even though "sustainable employment" as a term hardly ever occurs, the attractive assumption that greening our economy will create, rather than destroy, jobs, as we define them today, prevails. However, some argue that environmentally and socially sustainable employment requires more than greening the mainstream, market- and growth-oriented, development path [4-6].

One of the most common arguments against "beyond the mainstream" economic thinking claims that there are no policy measures offered that make an "alternative" path feasible to follow. It is rightly argued that complex socio-ecological systems cannot be controlled or managed and path dependencies and lock-in effects tend to prevail. However, non-action may still cost us too much, particularly to the vulnerable groups of society. This is the reason why one needs tools that can support in conceptualizing the transformation towards a sustainable society. The search for this kind of support in scientific literature has been termed transition management (TM). The TM approach attempts to determine policies that are able to facilitate such transformation under conditions of uncertainty, complexity, and need for continuous learning and adaptation [7,8]. Backcasting is one of the techniques applied by TM in order to identify policy measures along the path of more radical changes towards sustainability [9].

As opposed to extrapolation from the present to the future exercised in forecasting, backcasting starts with the establishment of a normative vision of the future and designs its way back to the present [10]. Backcasting thus supposes that decisions made today do influence our prospects and hence provide opportunities in moving towards a desired future. Backcasting exercises are necessarily participatory and deliberative involving a narrower or wider set of stakeholders in creating a shared vision and identifying the necessary policy measures. In the present article, a version of such a shared vision will be introduced based on two participatory exercises. The first two-day participatory backcasting workshop was organized in March 2012 with a panel of experts with relevant experiences in employment policy-making. The second workshop applying the same methodology was organized in January 2013 and involved university graduate students pursuing environmental studies. The paper presents the different elements that participants considered important regarding the future of sustainable employment, drawing attention to the similarities and diversities that the two different groups represented. These elements will also be linked to on-going scientific and policy discussions in order to gain an insight into what components the term sustainable employment may cover. These elements will be linked with, and discussed through, four main topics: the redefinition of work; globalization and localization and the role of communities; the role of technology in sustainable employment; and corporate and political governance. 
In this paper the expression of "future vision" will be used in line with Wright's expression of "real utopias". According to Wright it is essential to develop visions as normative ideals against which present social structures can be measured and necessary changes can be initiated. According to him, these "real utopias" should be visions for the future in which all human beings can live flourishing lives while they should also reflect upon the complexities and the multi-faceted nature of modern societies [11].

\section{Back from the Future: Backcasting for Sustainable Employment in Hungary}

Backcasting is one of the most often used methodologies in future studies ([12], p. 748). Participants in a backcasting exercise create a normative vision of the future (usually 25-50 years ahead) and move "backwards in time" to identify the necessary steps in order to connect this ideal version of the future to the present conditions [13]. While both forecasting and backcasting are useful and necessary in today's policy discourse, backcasting is preferable in the following cases. Firstly, where the future is uncertain as the heterogeneous systems involved are highly complex. Secondly, when the dominant trends of the present lead to dismal outcomes in the future; and thirdly, when significant and continuous social learning is needed in order to cope with rapidly changing natural, technological and social environment [14].

There are at least four different types of backcasting [15]. The process of the target-orientated backcasting is organized around a specific goal like a given percentage of $\mathrm{CO}_{2}$ reduction or energy-conservation. In these types of processes the main question is "what can change" in the socio-technical environment. This question often implies analysis of necessary changes in the technical infrastructures but possible changes in social structures can be also part of the analysis. In the pathway-orientated backcasting the main focus is on the development of the normative vision of the future. This means that the attainment of specific goals is downplayed, while the process is primarily explorative revealing different pathways. The main question of these types of projects is usually about "how change can take place". The third type of backcasting is the action-orientated backcasting, where the process aims to develop an action or a strategic plan. In order to do so, questions of "what can change and how to change" are both important. This version of the technique can be strongly associated with the approach of transition management. Thus, from this perspective, a shared vision of the future and a common strategy to reach this future can facilitate the harmonization of efforts of actors working for sustainable transitions. The fourth type is a participation-orientated backcasting which is essentially a creative workshop technique. This version emphasizes positive influences of the process on the participants themselves. So effects such as empowerment, social learning and community development are considered just as important, if not more, than other more tangible outcomes of the process ([15], p. 874).

Thematic frameworks are often used in deliberative and participatory methods (such as citizens' juries and consensus conferences) in order to structure deliberation and help participants reaching consensus in a contentious issue. Therefore, we also provided such framework on four foci of the topic of sustainable employment (community, environment, technology and individual capabilities) facilitating the creation of a shared future vision. The participatory nature of our exercise also meant, that unlike in other methods such as the Delphi survey [16], a relatively small group of stakeholders were involved. This number of participants was also based on the experiences and practice of deliberative and participatory methods such as citizens' juries, consensus conferences or scenario 
workshops $[17,18]$. In all these methodological techniques, the emphasis is more on meaningful participation and deliberation in a face-to-face setting allowing for more thorough discussions and analysis rather than on the extensive number of participants.

Applying the typology described above, our process can be categorized as a pathway-orientated backcasting exploring the possibilities of the future without identifying specific goals to reach in the future. However, involving various stakeholders in the creation of a normative vision of the future of work was another key characteristic of the process from the very beginning. Hence, our methodological approach can also be considered as partly participation-orientated.

Due to the agenda of the National Council for Sustainable Development, an advisory body to the Hungarian Parliament, the opportunity arose to investigate sustainability transitions and apply backcasting in the Hungarian sustainability policy context. A complex policy field of a fundamental significance was to be identified that incorporated technological elements, social patterns, as well as cultural factors and required the deliberation of experts with many different viewpoints. Sustainable employment was chosen - a policy field currently being high on the political agenda in Hungary (debating employment rate, social benefits, public work, etc.) and which is a complex and multi-faceted issue involving several stakeholders.

The originally planned Hungarian backcasting project organized one workshop and opted for an expert panel approach. The 16 participants came from varied backgrounds and from different sectors (academic, business, civil, and public) but were all in some ways related to employment issues. Having plenty of experience in their own fields of expertise, it also meant that the average age of the group was 46. After having analyzed the results of this first workshop, the organizers decided to run a second round of workshops with the same methodology but involving participants from a different age group with a different orientation in interests: 14 environmentally conscious Master students of human ecology and environmental economics. This opportunity gave the organizers a greater insight into how two different generations (with the second group's average age dropping to 26 years) with diverse viewpoints to the same topic would envision sustainable employment in Hungary in the year 2050.

After the workshops, the authors performed a qualitative data analysis on the notes and recordings using a combination of meaning-condensation; categorization and meaning-interpretation [19]. The elements of the visions of the two groups overlapped to a great extent. Therefore, the workshops resulted in one coherent normative vision with slight variations that will be indicated where relevant. In the next chapters, we will present how these two groups envision sustainable employment in the future and how this normative vision reflects on scientific discussions on the constituting elements of sustainable employment.

\section{Redefining Work}

Having a different conceptualization of the role that work plays in people's lives was the central focus by the participants of the backcasting workshops. Participants in both workshops found the redefinition of work crucial in their vision for sustainable employment. They claimed that in Hungary, in 2050 work is not merely a tool for basic subsistence but also a "source of well-being". Work does not consist only of paid jobs and does not only exist in institutionalized forms. As work is no longer just a struggle for survival, people have an internal motivation to do what they enjoy and skilled to do 
and what enables them to exploit their full personal potential. Everyone can be proud of their jobs and society appreciates all kind of work. Work is meaningful and useful in many different segments of life. Hence, work motivation changes accordingly: prime motivation is no longer subsistence (earning one's own living), as in market societies, but self-actualization, self-development and the feeling of social usefulness. As one of the participants phrased, "work is happy self-actualization in a socially beneficial manner".

This redefinition also prompts changes in our conceptualization of needs. Human needs go beyond the physical/material focus and intellectual/spiritual needs come to the forefront of activities. The satisfaction of needs is "healthy" (both materially and mentally), putting a stop to patterns of overconsumption. Such redefinition also facilitates the appreciation of human skills and labor over material consumption and this leads to "mending things rather than scrapping" as "we do not ditch other people's work". The new approaches to working lives also enable people to take more responsibility for and better care of their own natural and social environment.

According to the participants, such redefinition of work stipulates the broadening of the different employment forms. In Hungary of the 2050s, employment is not purely part of the market economy as people also do work that is "not necessarily monetized", so barter or working in Local Exchange and Trading Systems (LETS) are highly acknowledged and are no longer considered "shadow economy". Learning is also a recognized form of employment in all age groups and the value of education is fully appreciated as a form of enhancing human capital. Hence, one can engage flexibly in many different work activities, in many different legal forms, doing diverse, meaningful and acclaimed jobs. This enables people to retain more control over their own lives. The discussions on the redefinition of work in the future between the two different groups bore striking resemblance to each other. However, the younger, environmentally-conscious group also contemplated the notions of work-time reductions and initiating changes in production in order to reduce the pace and monotony of labor and increase the value added to the process by the workforce.

Both groups agreed that, in order to facilitate such redefinition of work, the desired policy tools focused on the objective that work done beyond the economic sphere dominated by monetary exchange relations (such as community and household work, and activities for self-development) should get recognition in order to provide people with the choice to work in many different employment forms. This implies that the legal and social system should embrace and encourage employment forms beyond paid labor (such as self-employment, household employment, LETS, barter and all atypical employment forms). In order to achieve these objectives, current administrative obstacles need to be abolished; new legislative and regulatory frameworks should be introduced for those elements that are currently unavailable; and communication campaigns and financial incentives should be initiated to change the attitude towards work. In both groups, the introduction of the guaranteed basic income was also heavily debated as a tool for enabling the transformation of employment circumstances.

In the relevant scientific literature, ecological modernization concepts on linking employment to sustainability advocate the greening of the market economy [20]. They imply that, with the rise of new eco-efficient technologies and the raised awareness of consumers, a new market for environmentally conscious goods and services will emerge. These trends will not only lead the economy towards reduced pollution and waste levels but, at the same time, also create new employment through green jobs. 
Eco-taxes play a significant role in this transformation as they are supposed to produce a so-called "double-dividend" effect [21]. By re-structuring taxes from burdening human labor to the use of natural capital, economic actors will smoothly change their behavior and economize on natural resources while employing more labor. However, these ideals require no major changes in our ways of thinking and living and do not touch upon the social and political status quo. Even though participants of the workshops were well aware of the "green growth and green job" perspectives, they continuously felt the need to move beyond these concepts. Nonetheless, they also suggested shifting tax burdens from labor to production related negative externalities but only as a transitory measure until changes in people's "mentalities" occur.

As opposed to the mainstream view of ecological modernization, the radical change paradigm literature disposes of the concepts of the free market society and claims that new "great transformations" are unavoidable [22], whereby values must change just as much as institutions. Representatives of the radical change paradigm refuse to accept the definition of welfare solely in terms of levels of consumption and the characterization of work as purely paid labor [4,5,23]. Radical change perspectives regarding employment are based upon the idea that different mental and institutional frameworks can be constructed under which the meaning of human needs and work can be redefined [24]. Highly resembling to that of the backcasting results, from this point of view, work is not purely a way of providing basic subsistence, or a necessary bad (negative utility), in life to reach higher levels of personal consumption but an essential part of both personal well-being and of well-functioning social relationships. In the last decades, numerous economists have called for the redefinition of well-being and the inclusion of many more components beyond the utility gained from personal consumption [24-26].

The dilemma, however, does not just lie with the definition of welfare but also with the notion of spare time. As Røpke [27] explored, following the labor productivity gains of the last centuries, employers chose to pay more for workers rather than turn the gains into spare time. Moreover, time spent at the workplace became a significant factor in the assessment of individual performance and lately overtime has turned into almost a prerequisite for advancement. At the same time, workers got used to higher levels of spending that discouraged them to trade-off work with spare time. This implies that those in employment face the problem of free time scarcity, restricting them to express skills and creativity outside of work, even if they possess the resources to do so, through consumption, while those out of employment may have the time, but lack the financial resources. This all leads to the predicament that, as long as the value of human labor does not play a role in utility decisions, individuals as consumers assist in maintaining jobs that disable the flourishing of human capabilities.

However, following such a redefinition, even with a fall of average consumption levels well-being and social relationships can be maintained or even enhanced through reducing working time [28,29]. Such changes in attitudes can be supported through schemes like the guaranteed basic income that would allow for essential subsistence for all citizens while freeing them from de-humanizing labor relationships [30]. These new meanings of work would make way for changes and open opportunities in community work, social enterprises, as they would no longer be merely a haven for those crowded out of the labor market. The shift from material consumption to fulfilling other human needs would not only help current employment problems but also lead to environmental sustainability [4,5]. Hence, 
redefining our perspectives towards work itself constitutes a major factor in sustainable employment. This approach was echoed in the normative visions and backcasted policy steps by both backcasting groups.

\section{Globalization and Localization and the Role of Communities}

Participants in both groups envisage the Hungarian society in 2050 where the role of communities is of rising importance and builds on values of cooperation, trust and solidarity. Community ties of individuals are strong and communal events are frequent. The network of trust is operational and trust itself is treated as a prime social asset. Community plays two different roles in employment. On the one hand, community provides a framework and motivation to work. On the other hand, work serves community purposes. As "people cannot have their work appreciated in larger spaces and large societies", society operates as a network of many smaller communities. Hence, both working in the community and working for the community becomes important. The group of master students also envisioned a wide variety of communal services and spaces like community kitchens, gardens, or laundry facilities. They all suggested speeding up current efforts to build social economy as a policy tool to involve the notion of community within employment.

In both workshops, the issue of "global vs. local" continuously resurfaced in the discussions. However, in the expert panel anti-global sentiments did not occur and the concept of the global economy and global society were not questioned at all. According to their vision, in 2050 globalization is more of a global network of local economies and societies, where local production and consumption, and hence local employment play a significant role. This does not imply at all that there is any limitation on goods and services imported from the global arena, only that local products and services enjoy certain advantages. Work is performed predominantly locally, or even from home, but so-called "office café" solutions also exist where people can work outside their homes. Employees are also free to choose whether they work locally or globally (as this adds to the desired diversity of working arrangements) but the pressure on mobility eases. Individuals may have strong ties to a locality but this indicates more the solidarity with a given community than the lack of mobility. (On the necessity of mobility, participants were divided.) Regarding the suggested policy options, local employment should be fully supported but barriers to global employment should also be eased at the same time, leaving the individuals the option to decide.

This was, however, slightly different in the younger, university student group. Presumably due to their higher level of environmental awareness, they were more critical towards globalization. In their vision, local production and consumption and self-reliance of communities is the key to sustainable employment and the movement of goods are limited to those that require significant know-how (like pharmaceuticals). Hence, the policy suggestions - besides the support of localization by all means available, including the use of local currencies as part of wage payments - also entailed significant renegotiations of global trading agreements in a way that provides all countries an equal chance to rely on their own resources and flourish without the exploitation through foreign trade by the economically more powerful. They also envisioned a world with significantly less mobility in employment.

In current economic literature, concepts consistently revolve around individuals and any behavior that diverts from the self-centered, utility maximizing actions does not only reflect irrationality in theory but is increasingly hard to find in practice, too [31]. In economic reasoning, individuals decide in 
a strictly rational manner and emotional aspects or the well-being of others do not directly play a role (except through influencing subjective preference ranking). In this theoretical framework, the vision of society is a fragmented one, consisting of individuals that take little consideration of society's interests.

Moreover, the value of community relationships receives little attention as they have no function in the operation of the market. In extreme cases, community considerations disrupt markets as they constrain the mobility of the workforce, and locally organized production and consumption networks distort competition (resulting in inefficiency and loss of welfare). In market economies, community interests are supposed to be safeguarded by institutions that are to adjust the failures of the markets. In this mechanism, the individuals' societal responsibilities decline as they are not required to take personal steps towards preserving community interests. However, the aforementioned concept covers a complicated contradiction. One of the main driving forces behind consumption is status-seeking [32], which is coerced by the desire to belong to a reference group in society. So, while social belonging is a crucial element in economic activities, the considerations for individual responsibility towards community benefits can be ignored as these are transferred to abstract institutions. Consumption societies therefore face the paradox that achieving higher status in society requires more earnings and takes time away from social activities, while those that have free time (like the unemployed) would not achieve the same social recognition. This is the paradox that was supposed to be alleviated in the community-centered vision of the Hungarian backcasting exercise through the strengthening of community ties by the means of establishing robust ties to localities.

As Beck [23] puts it, we live in the paradox of social proximity and geographical remoteness. This means that global integration has led us to feel conflicts in faraway lands socially close to us if it concerns our social class [23]. At the same time, we may live close to others and still feel no solidarity. This is the reason why - similarly to the normative vision of the participants-eco-localism is often an advocated answer in the literature as well when it comes to sustainability. Eco-localism supports both environmental sustainability and social cohesion through local production and consumption networks that place the locally available resources (environmental, social, physical, and human capital) in the forefront of economic and social activity and hence encourage moving towards self-reliance [33]. This is the reason why it also often occurs in the relevant literature as a tool for establishing better employment conditions $[33,34]$. There already exist successful initiatives where labor and products are traded at the local community level, sometimes not even involving monetary exchange [35].

The policy and scientific discussions on the importance of the social economy are also linked to the debate on localism. The report of CIRIEC [36] describes how the social economy contributes significantly to supporting local sustainable grass-root initiatives in many different sectors, from general regional development projects to the rehabilitation of dilapidated industrial sites. Their distinct mechanisms from for-profit enterprises also enable them to distribute income and produced goods more evenly and hence have significant impact on the overall welfare of local societies [36].

From the above it seems that even though participants may be divided on the extent to which globalization should be allowed to penetrate local economies, they all seem to desire a significant move towards a more locally-organized, community-based society that advocates eco-localism as an essential part of sustainability in general, and sustainable employment in particular. 


\section{The Role of Technology in Sustainable Employment}

The participants of the expert panel revealed outstanding technological optimism and technological determinism. "In 2050 technologies will be widely accessible that we have no knowledge of today." They envisioned that even though in 2050 less work is available due to technological advances, this does not imply higher unemployment but rather more opportunities for redefining work. Technology supports flexible working arrangements, improvements in quality of living, substitution of arduous and monotonous jobs, equal access to work and public services and participatory decision-making. The wide-ranging research and development activities do not only cover technological advancement but social innovations as well. While not questioning technological advances at all, much emphasis was also put on the preservation of traditional cultural values, and the safeguarding of those who work with traditional technologies. The backcasted policy measures all aimed at establishing the role of technology in supporting sustainable employment by encouraging targeted technological and social innovations through financial incentives. They included a wide-range of potential applications from the introduction of trust-building, participatory community decision-making; through boosting the creative industry, until facilitating equal access to employment, locations and services. This group of policy instruments also included those that prevent the disappearance of traditional professions.

It is remarkable that, while the younger participants in the backcasting exercise also envisioned a future where technology supports self-reliance and self-development, as opposed to the other group, they were highly critical of technological advancement and phrased their normative vision accordingly. They declared that in their vision "it is technology that serves humans and not humans serving technology". In 2050, society is not afraid of discarding certain technological advances and the purpose of technology is not to replace but to complement human skills, strengths and creativity. It serves to diversify local opportunities to use local resources rather than to create path dependencies. Knowledge behind technology is open-source and accessible to all. The backcasted policy measures they suggested also reflected their critical approach to technology focusing on avoiding planned obsolescence and ensuring that technology serves local self-reliance rather than global injustice.

In the relevant scientific literature, technology plays a crucial but rather controversial role both in the concept of sustainability and in its relationship with employment. Market economies lay significant emphasis on technological advances both in terms of increasing productivity through creative destruction and, over time as the path that leads economic growth to sustainability, through technological fixes. The effect of the Schumpeterian creative destruction [37] on employment has long been known. The dynamics of the current economic system continuously foster innovation that make whole industries together with their workers and their skills obsolete, while new industries with new technologies and new demand for employment occur. In theory, after a phase of structural unemployment, no losses are registered as resources only re-allocated between old and new industries. These transition periods demand re-training of the labor force and increased labor mobility that are not as fast in practice as the theory may suggest and incur significant social and environmental costs. Moreover, as innovations are also aimed at increasing efficiency that steer costs down, including labor costs, technological advances also lead to the loss of jobs [4].

The issue of technological fixes is highly opportune in the times of sustainability concerns. As Ekins [38] declares there is a growing consensus that the current economic development is 
ecologically unsustainable, but the differences in our approaches towards what role technology may play in our transition towards sustainability occur mainly due to the differing scales of the individuals' technological optimisms. The gravest trap certainly lies with the elevated optimism that technological fixes can save the day. The belief that technology acts as a tool for de-coupling environmental pressures from growing consumption can overwrite the all-important issue of scale and maintain an unfounded sense of security that business can go on as usual [4]. With regard to employment, technological fixes are supposed to be the main drivers of green jobs and hence should have serious impacts on current employment levels. However, technological advances are significantly more capital than labor intensive, and if the cost of capital keeps driving real wages down as have done in the past [39], the double-dip effect of dropping wages and lowered purchasing power leading to more pressure on employment may become even more severe. This indicates that the rift between the two backcasting groups being technologically optimistic and pessimistic in terms of technology playing a significant and controversial role in sustainable employment occurs just as divisive in the relevant scientific literature.

\section{Institutional Framework for Sustainability: Corporate and Political Governance}

The participants of both groups envision the economic actors of 2050 not merely either for-profit or non-profit organizations. For-profit actors are sensitized (or coerced into) being environmentally and socially responsible organizations that build these aspects into their everyday decision-making and serve community values. Management culture embraces empowerment, where employees have certain degrees of self-determination. Bonuses include solutions that facilitate the new, diverse types of employment such as sabbaticals or work-time allowances for volunteering activities. Consultations with workers' associations are based on trust and dialogue, where both parties are present as partners. In case of inevitable downsizing, outplacement services are provided on a wide basis to employees. Different co-ownership schemes for workers are common, cooperatives are rediscovered and many work in the predominantly non-profit social economy.

The expert panel also added to their vision that as in the for-profit sector corporate social responsibility becomes the norm, at the same time corporate governance becomes widespread among non-profit organizations. Hence, non-profit approaches are built into the operations of for-profit companies, while non-profit organizations internalize the essentials of economic operations. Accordingly, the backcasted policy measures focused on supporting non-profit organizations to become an integrated part of the economy. At the same time the suggested interventions were for encouraging for-profit companies to take on board social values, ensuring that people work in an environment that is based on cooperation and trust and embraces real social dialogue.

During discussions, a vision of the Hungarian state in 2050 was also crystallized. The participants in both groups envisage that in 2050 Hungary is a democracy but one that is significantly more decentralized both in terms of decision-making and financial resources than today. Even though participatory or deliberative democracy as a term never occurred during discussions, the topic of a state where individual, community, and state responsibilities are clearly distinguished and decisions are taken on the levels where responsibility lies often appeared. The recommended policy tools revolved around the issue of interventions that could lead to better cooperation and more solidarity on a socio-political 
level. These are to be achieved through establishing social trust, for example, by introducing trust building elements into public administration like encouraging real participatory social dialogue.

Literature on sustainable business models also include elements similar to those raised by the participants. Stubbs and Coclin [40] suggest that in order to become sustainable, an organization must embrace notions of social and environmental priorities such as environmental stewardship, respect for people and nature, and social equity. This, however, requires a whole new way of handling stakeholder engagement that goes well beyond the mainstream shareholder perspective, as well as the instrumental stakeholder perspective. The social characteristics of a sustainable business model include stakeholder engagement skills such as understanding stakeholders' needs and expectations as well as relationship building abilities that foster trust, two-way dialogue, loyalty, honesty, integrity, fairness, and equity [40].

According to the literature on political participation, the major factor behind the widespread demand for participatory opportunities is connected to the decline of state power and political order. In this respect, participation is a key to reach political order, enhance legitimacy and the quality of decisions. According to Habermas [41], one of the preconditions that must be met if society wants to regulate their coexistence democratically and to shape social conditions by political means is that "there must be a citizenry that can be mobilized for participation in political opinion-formation and will-formation oriented to the common good" ([41], p. 76).

There are two key elements in the normative visions of the two groups that shed light on the notion of sustainable employment regarding this topic. Firstly, real participatory social dialogue is needed both in the economic and the political sphere. Secondly, for-profit entities should be transformed back into what they really are: social constructions ultimately serving the public good.

\section{Discussion and Conclusions}

Hawken, Lovins and Lovins in their book, "Natural Capitalism: The Next Industrial Revolution" [42] concisely summarized the problem sustainable employment faces in our times:

"At the beginning of the industrial revolution, labour was overworked and relatively scarce (the population was about one-tenth of current totals), while global stocks of natural capital were abundant and unexploited. But today the situation has been reversed: After two centuries of rise in labour productivity, the liquidation of natural resources at their extraction cost rather than their replacement value, and the exploitation of living systems as if they were free, infinite, and in perpetual renewal, it is people who have become abundant resource, while nature is becoming disturbingly scarce.” ([42], p. 8).

Attempts to find solutions to this problem prompt both political decision-makers and academics to try and combine endeavors in the economic, social and environmental spheres. The ever-growing technological optimism has led to the diffusion of the green economy concept where investments into environmentally sustainable production and consumption would produce a sustainable society without compromising economic growth and, at the same time, employment prospects. It promises a "quick fix" to economic recession and employment problems while reducing carbon emissions and other environmentally harmful economic activities without initiating major changes either in our ways of thinking or in our ways of living. 
Environmental sustainability, however, is often defined in two different ways. The so-called weak sustainability signifies the underlying concept that natural and man-made capitals can be substituted with each other and the level of consumption can be maintained as long as a possibly decreasing level of natural capital is compensated for by the increase in man-made and/or human capital. In contrast, strong sustainability does not allow for such a perfect substitution and insists that the stock of natural capital should remain constant in order to have future generations the possibility to enjoy the flows that nature provides [4]. The authors of the present paper believe that strong sustainability is a call for our responsibility for the Biosphere, its human and non-human creatures and systems. Most probably, jobs and employment will need a re-definition accordingly.

As opposed to the ecological modernization approach, the radical change paradigm attempts to deal with the limits of the Biosphere's supporting capacities, hence aiming to achieve strong environmental sustainability. In terms of social sustainability, this paradigm aims to address the problems of unequal distribution, the widening social gap, and decreasing social solidarity. While ecological modernization may provide solutions in the short-term, strong environmental and social sustainability is likely to be achieved only by overstepping the theoretical boundaries of current paradigms.

However, "thinking out of the box" requires new approaches and, as Wright [10] calls it, "real utopias". While alternative economic thinking may be considered unrealistic in current policy making as the complexity and path dependency of our social and economic systems discourage decision-makers to leave known grounds behind, post-normal science acknowledges the fact that there are no clear-cut answers to questions like sustainability — or more specifically, sustainable employment in our case — but the quest itself to find viable solutions beyond our everyday horizon of thinking may lead us in the right direction. This paper presented the application of one particular method that facilitates this pursuit: the technique of backcasting.

When two distinct groups were provided with the opportunity to envision "the future we want in the world of work", they constructed surprisingly similar answers. The participants' vision for sustainable employment in Hungary in 2050 contained mixed elements of the ecological modernization and radical change paradigms. Their vision abandoned the ideal of full employment and made way for a life where people are free to work not because they are forced by their subsistence but because work is an activity that serves the well-being of both their community and themselves. Well-being was defined not only in material terms but also in terms of self-development; self-fulfillment; sufficient time for nurturing family and community relationships and access to a healthy environment. This approach would enrich the forms of employment and dispose of the idea that employment generally means a 40-hour paid labor week. Participants truly believed that localized employment through the encouragement of local production and consumption patterns would contribute significantly to sustainable employment.

It is, however, as important to note the differences that the two groups demonstrated as the similarities. Significant differences arose in three main areas: in their acceptance of globalization, their attitude towards technology and in their choices of policy tools. The first two are supposedly due to the fact that the group of graduate students that was rather skeptical of and, in their recommendations, expressed a more radical stance against globalization was also more environmentally conscious. Environmental activism often involves a more critical view on current globalization trends and technological advancement. The third difference is more likely to stem from the age gap and the distinct work experience. The expert panel focused more on awareness-raising tools that were aimed at 
changing the way people think, while the younger group truly believed in legal tools, such as legislation and regulation. As most of those in the expert panel have been working in jobs where they are creating regulatory change without having experiencing real breakthroughs, they seemed to believe more in the power of people's mind than the power of the law.

In Hungary, the political discourse on employment seems to revolve around three main concepts [3]. Firstly, in line with the mainstream economic paradigm, flexibility of the labor market is emphasized even if it means that legislation protects employers' interests over those of employees. Secondly, public work schemes are supposed to provide for those excluded from the primary labor market. Thirdly, investments into green technology are expected to create job opportunities. However, as was highlighted by the backcasting exercises reported above, these interventions are not necessarily fully in line with what sustainable employment is considered to embrace. Moreover, political efforts at European level [2] that aim to strengthen the social economy, acknowledge and legalize household and care-taking jobs, invest in community-building and the civil sector, enhance corporate social responsibility or support social dialogue may constitute steps in the direction embraced by the vision of employment in line of strong sustainability as presented earlier in this paper.

The authors acknowledge that this vision reflects the co-construction of 30 individuals in Hungary. However, this qualitative technique facilitates real participation thorough deliberation and active exchange of ideas between participants resulting in learning and shared understanding. Hence, it provides an in-depth insight that some other decision-support techniques with wider involvement may not generate. The participants' attempt to create a normative vision of the future and suggest a path that may lead us there sheds some light on how people think of sustainable employment and which theoretical approaches are being involved in their desires for a more sustainable society. Moreover, experimental backcasting projects, like the one in Hungary reported here, can contribute to our understanding of what the term sustainable employment may mean. As a result, suggested policy tools that make the mushrooming of different employment forms possible; genuinely encourage the establishment of a social economy; support local production and consumption and facilitate truly participatory and deliberative social dialogue on contentious issues, such as guaranteed basic income or the changing role of the state, may one day actually guide us towards such a sustainable employment.

\section{Acknowledgments}

This research project was financed by the National Council for Sustainable Development, Hungary. We gratefully acknowledge the personal support of Gábor Bartus and the members of the Environmental Social Science Research Group. We wish to thank the participants of the backcasting workshops for devoting their time and sharing their insights with us. The publication of this paper was supported by the TÁMOP 4.2.2/B-10/1-2010-0023 project implemented by the Corvinus University of Budapest financed by the Hungarian Government and co-financed by the European Union. The usual caveats apply.

\section{Conflict of Interest}

The authors declare no conflict of interest. 


\section{References}

1. UNEP. Green Jobs: Towards Decent Work in a Sustainable, Low-carbon World; EP 8-08 \#200763569; United Nations Environment Programme: Nairobi, Kenya, 2008.

2. European Commission. Europe 2020: A European Strategy for Smart, Sustainable and Inclusive Growth; European Commission: Brussels, Belgium, 2010.

3. Hungarian Government. Széll Kálmán Work Plan (in Hungarian); Ministry of National Economy: Budapest, Hungary, 2012.

4. Jackson, T. Prosperity without Growth? The Transition to a Sustainable Economy; UK Sustainable Development Commission: London, UK, 2010.

5. Costanza, R.; Alperovitz, G.; Daly, H.E.; Farley, J.; Franco, C.; Jackson, T.; Kubiszewski, I.; Schor, J.; Victor, P. Building a Sustainable and Desirable Economy-in-Society-in-Nature; United Nations, Division for Sustainable Development: New York, NY, USA, 2012.

6. Martínez-Alier, J.; Pascual, U.; Vivien, F.-D.; Zaccai, E. Sustainable de-growth: Mapping the context, criticisms and future prospects of an emergent paradigm. Ecol. Econ. 2010, 69, 1741-1747.

7. Grin, J.; Rotmans, J.; Schot, J.; Geels, F.; Loorbach, D. Transitions to Sustainable Development; New Directions in the Study of Long Term Transformative Change; Routledge: New York, NY, USA, London, UK, 2010.

8. Loorbach, D. Governance for sustainability. Sustain.: Sci. Pract. Policy 2007, 42, 1-4.

9. Van der Meer, M.; Visser, J.; Wilthagen, T. Adaptive and reflexive governance: The limits of organized decentralization. Eur. J. Ind. Relat. 2005, 11, 347-365.

10. Höjer, M.; Mattsson, L.-G. Determinism and backcasting in future studies. Futures 2000, 32, 613-634.

11. Wright, E.O. Transforming capitalism through real utopias. Amer. Sociol. Rev. 2012, 78, 1-25.

12. Vergragt, P.J.; Quist, J. Backcasting for sustainability: Introduction to the special issue. Technol. Forecast. Soc. Change 2011, 78, 747-755.

13. Robinson, J. Future subjunctive: Backcasting as social learning. Futures 2003, 35, 839-856.

14. Joint Research Centre. Backcasting approach for sustainable mobility. Available online: http://www.mcrit.com/transvisions/documents/sectorial/transport/backcasting\%20final\%20report. pdf (accessed on 13 April 2012).

15. Wangel, J. Exploring social structures and agency in backcasting studies for sustainable development. Technol. Forecast. Soc. Change 2011, 78, 872-882.

16. Turoff, M. The design of a policy delphi. Technol. Forecast. Soc. Change. 1970, 2, 149-171.

17. Smith, G.; Wales, C. Citizens' juries and deliberative democracy. Polit. Stud. 2000, 48, 51-65.

18. Andersen, I.-E.; Jæger, B. Scenario workshops and consensus conferences: Towards more democratic decision-making. Sci. Public Policy 1999, 26, 331-340.

19. Kvale, S. InterViews. An Introduction to Qualitative Research Interviewing; Sage: Thousand Oaks, CA, USA, 1996.

20. Mol, A.P.J. Ecological Modernization: Industrial Transformations and Environmental Reform. In The International Handbook of Environmental Sociology; Redclift, M., Ed.; Edward Elgar: Cheltenham, UK, 1997; pp. 138-149. 
21. Goodstein, E. Labor supply and the double-dividend. Ecol. Econ. 2002, 42, 101-106.

22. Raskin, P.; Banuri, T.; Gallopin, G.; Gutman, P.; Hammond, A. Great Transition: The Promise and Lure of the Times Ahead; Stockholm Environmental Institute-Tellus Institute: Boston, MA, USA, 2002.

23. Beck, U. A Munka Szép új Világa (In Hungarian); Belvedere: Szeged, Hungary, 2007.

24. Soper, K. Conceptualizing needs in the context of consumer politics. J. Consum. Policy 2007, 29, 355-372.

25. Hirsch, F. Social Limits to Growth; Routledge \& Kegan Paul: London, UK, 1977.

26. Pearce, D. Measuring Sustainable Development; Earthscan Publications Ltd.: London, UK, 1993.

27. Røpke, I. The dynamics of willingness to consume. Ecol. Econ. 1999, 28, 399-420.

28. Sanne, C. Willing consumers - or locked-in? Policies for a sustainable consumption. Ecol. Econ. 2002, 42, 273-287.

29. Schor, J.B. Sustainable consumption and worktime reduction. J. Ind. Ecol. 2005, 9, 37-50.

30. Van Parijs, P. A Basic Income for All. Boston Review 2000, 25, 4-8.

31. O’Hara, S.U. Valuing socio-diversity. Int. J. Soc. Econ. 1995, 22, 31-49.

32. Brekke, K.A.; Howarth, R.B.; Nyborg, K. Status-seeking and material affluence: Evaluating the Hirsch hypothesis. Ecol. Econ. 2003, 45, 29-39.

33. Curtis, F. Eco-localism and sustainability. Ecol. Econ. 2003, 46, 83-102.

34. Gray, R. Practical bioregionalism: A philosophy for a sustainable future and a hypothetical transition strategy for Armidale, New South Wales, Australia. Futures 2007, 39, 790-806.

35. Seyfang, G.; Longhurst, N. Growing green money? Mapping community currencies for sustainable development. Ecol. Econ. 2013, 86, 65-77.

36. CIRIEC (International Centre of Research and Information on the Public Social and Cooperative Economy). The Social Economy in the European Union; No. CESE/COMM/05/2005; The European Economic and Social Committee: Brussels, Belgium, 2007.

37. Schumpeter, J.A. Capitalism, Socialism and Democracy, 5th ed.; George Allen and Unwin: London, UK, 1976.

38. Ekins, P. A Növekedés határai és a Fenntartható Fejlődés: Megbirkózni az Ökológiai Valósággal. In Természet és Gazdaság. Ökológiai Közgazdaságtan Szöveggyüjtemény (in Hungarian); Pataki, G.,Takács-Sánta, A., Eds.; Typotex: Budapest, Hungary, 2004; pp. 267-292.

39. International Labour Organisation. World of Work Report; 978-92-9014-975-0; International Institute for Labour Studies: Geneva, Switzerland, 2011.

40. Stubbs, W.; Cocklin, C. Conceptualizing a 'Sustainability Business Model'. Organ. Environ. 2008, 21, 103-127.

41. Habermas, J. Zeit der Übergaenge (in German). Suhrkamp Verlag: Frankfurt am Main, Germany, 2001.

42. Hawken, P.; Lovins, A.B.; Lovins, L.H. Natural Capitalism: The Next Industrial Revolution; Earthscan Publications: London, UK, 1999.

(C) 2013 by the authors; licensee MDPI, Basel, Switzerland. This article is an open access article distributed under the terms and conditions of the Creative Commons Attribution license (http://creativecommons.org/licenses/by/3.0/). 